Boletín de la Sociedad Geológica Mexicana

VOLUMEN 61, NÚM 1, 2009, P. 111-118

\title{
Characteristics of 2004 tsunami deposits of the northern Tamil Nadu coast, southeastern India
}

\author{
S. Srinivasalu ${ }^{1, *}$, N. Rajeshwara Rao ${ }^{2}$, N. Thangadurai ${ }^{1}$, M. P. Jonathan ${ }^{3}$, P. D. Roy ${ }^{4}$, V. Ram Mohan ${ }^{5}$, \\ P. Saravanan ${ }^{1}$
}

${ }^{1}$ Department of Geology, Anna University, 600025 Chennai, India

${ }^{2}$ Department of Applied Geology, University of Madras, Guindy campus, 600025 Chennai, India

${ }^{3}$ Centro de Investigaciones en Ciencias de la Tierra y Materiales, Universidad Autónoma del Estado de Hidalgo, Ciudad Universitaria, 42184 Pachuca, Hidalgo, Mexico.

${ }^{4}$ Instituto de Geología, Departamento de Geoquímica, Universidad Nacional Autónoma de México, Ciudad Universitaria, 04510 México D.F., México

${ }^{5}$ Department of Geology, University of Madras, Guindy campus, 600025 Chennai, India

\begin{abstract}
The 2004 Indian Ocean tsunami left significant sand deposits along the coastal tract of southeast India (Tamil Nadu state). These deposits serve as a benchmark to understand the effects of present day tsunami on the coastline. Additionally, the geological signatures of tsunami in the coastal stratigraphy can assist in providing modern analogs for identification and interpretation of ancient tsunami. This article presents the field observations of tsunami deposits, their internal stratigraphy and foraminiferal distribution, all of which varied from north to south depending upon coastal geomorphology, near shore bathymetry and sediment sources. In a few places, the tsunami deposits have been reworked due to subsequent events that caused modification in the internal stratigraphy. The tsunami deposits of the northern Tamil Nadu coast comprise at least $50 \%$ or more reworked foraminiferal specimens, indicating that the tsunami sediments may have been derived from a paleostrandline from a water depth of at least $45 \mathrm{~m}$
\end{abstract}

Key words: 2004 tsunami, geomorphology, foraminifera, sand deposits, southeast coast of India.

Resumen

El tsunami de 2004 en el Océano Índico acumuló una capa de sedimentos gruesos (depósitos de arena) a lo largo de la costa sureste de la India, particularmente en el estado de Tamil Nadu. Esos depósitos sedimentarios sirven como referencia para entender los efectos de tsunamis actuales en las zonas costeras. Además, las características geológicas de los depósitos de tsunami actuales en la estratigrafía costera asisten en identificación e interpretación de los tsunamis antiguos. En este artículo presentamos las observaciones del campo sobre los depósitos de tsunami, su estratigrafía interna y distribución de foraminíferos según varía de norte a sur, dependiendo de la geomorfología costera, de la batimetría somera, y de la proveniencia de los sedimentos. En algunas localidades, la estratigrafía interna de los depósitos fue perturbada debido a eventos subsiguientes. Los depósitos de tsunami de 2004 en la costa norte de Tamil Nadu constituyen al menos $50 \%$ o más de las foraminíferas retransportadas, lo cual indica que los sedimentos de tsunami fueron derivados de un paleo-costa, actualmente ubicado a una profundidad de al menos $45 \mathrm{~m}$.

Palabras clave: tsunami de 2004, geomorfología, foraminífera, depósitos de arena, costa sureste de la India.

\section{Introduction}

The study of recent tsunami deposits is important for recognition of similar events in the geological record and understanding their effects on the coastal regions, i.e. by calculating inundation limits (the distance to which tsunami deposits were transported inland) and run up (the maximum height of the tsunami wave). Based on sedimentological 
characteristics, prehistoric tsunamis are identified in the Pacific Northwest (Atwater and Moore, 1992; Benson et al., 1997), Cascadian subduction zone (Darienzo and Peterson, 1995; Peters et al., 2001), Hawaii (Moore, 2000), Kamchatka (Pinegina et al., 2003), Japan (Nanayama et al., 2003), Chile (Cisternas et al., 2005), northern Sumatra (Monecke et al., 2008) and Thailand (Jankaew et al., 2008), etc.

However, the tsunami sediments undergo various changes from deposition to observation. Post depositional alterations of tsunami deposits by wave action, stream erosion, winnowing by wind, rain, biogenic alteration and human activities may decrease their preservation potential in some areas and increase it in others, thus causing erroneous calculation of tsunami inundation estimates for ancient events (Jaffe et al., 2006; Moore et al., 2006; Satake and Atwater, 2007). In many cases, the alterations change the lateral extent, thickness and complex internal stratigraphy of the tsunami deposits. These distortions of the original stratigraphy could also be caused by bio- and pedo-turbation, selective winnowing of fine grain sizes and outright dissolution of grains. Hence, there is a need to understand the factors that contribute to the alteration of recent sediment deposits and quantify the rate/magnitude of those changes to make possible estimates of ancient tsunami inundation (Atwater, 2007; Srinivasalu et al., 2007a).

Furthermore, the lack of knowledge in differentiating a tsunami from a storm deposit has led to extensive debate on the identification of several published paleotsunami deposits in coastal regions (Bryant et al., 1992; Moore and Moore, 1984). Recently, Goff et al. (2004) presented the characteristics that differentiate the 2002 storm deposits and $15^{\text {th }}$ century tsunami deposits on the southeast coast of the North Island, New Zealand based on aerial extent, thickness and grain size characteristics. However more such studies are required where both the tsunami and storm deposits are present along the same stretch of coastline.

The $26^{\text {th }}$ December 2004 Indian Ocean tsunami affected both the southeastern and southwestern coastal regions of India, i.e. Andaman and Nicobar Islands, states of Andhra Pradesh and Tamil Nadu on the southeast coast and parts of Kerala state on the southwest coast. Laterally extensive sand sheet tsunami deposits provide a valuable modern-day analogue for comparison with past wash over deposits of unknown origin. Substantial efforts have gone into mapping the tsunami deposits, their sedimentological characteristics and foraminiferal assemblages along the southeast coast of India, mostly between Chennai and Vedharanyam (Figure 1) (Nagendra et al., 2005; Srinivasalu et al., 2005; Seralathan et al., 2006; Srinivasalu et al., 2007b). The detailed measurements of coastal topography, tsunami flow height, and deposit thickness were made from Chennai to Thiruchendur (approximately $900 \mathrm{~km}$ coastal tract) and many transects were examined in detail to assess the sedimentology and spatial distribution of the tsunami deposits (Srinivasalu et al., 2005; Seralathan et al., 2006; Thangadurai et al., 2005, 2006; Srinivasalu et al., 2007b). In many places on the southeast coast of India, distinctive layers of sand deposits of marine origin cover the landscape and overlie the muddy soils of the coastal plain. In this article, we present the depositional pattern of modern tsunami deposits and the foraminiferal distribution from southeast coast of India between Chennai and Vedharanyam in Tamil Nadu state (Figure 1).

\section{Study area}

The study area covers approximately $500 \mathrm{~km}$ of coastal tract from Chennai in the north to Vedharanyam in the south, along the southeast Indian coast (Figure 1). The landforms in the northern part of the study area are characterized by low angle siliclastic beaches with an average width of about 50 to $100 \mathrm{~m}$ and are backed by coastal sand dunes of $<5 \mathrm{~m}$ elevation. The coastal barrier consists of a variety of geomorphic units such as stranded beach ridges (paleo-barriers), paleo-lagoons and paleo-tidal flats (Anbarasu, 1994). Two prominent sets of well-developed beach ridges, exhibiting typical strand line features almost parallel to the shore, are present along much of the northern study area. The southern part of the study area comprises a complex delta dominated by silty flood plain sediments, strandlines, beach ridges and tidal flats that overlie

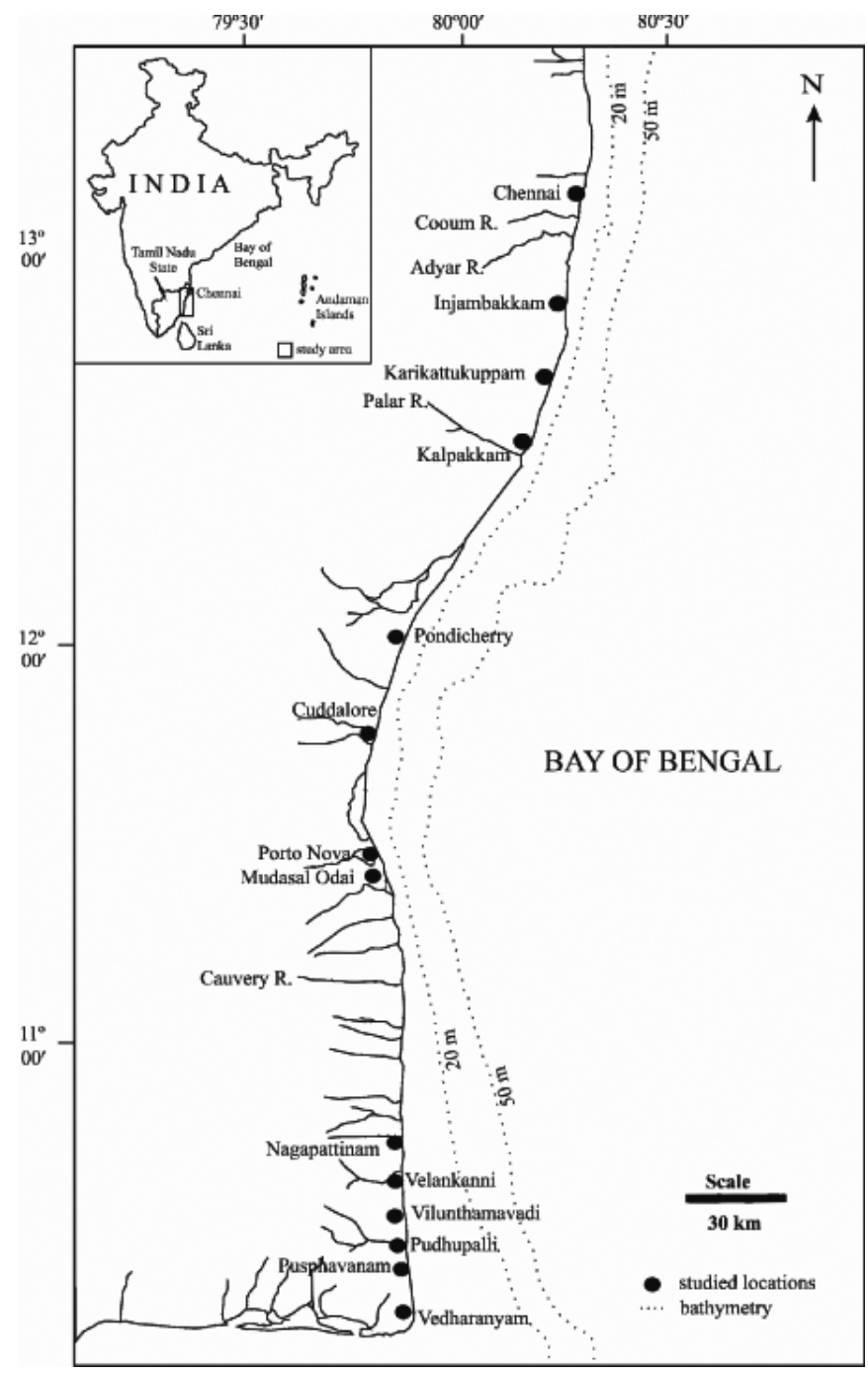

Figure 1. Study area map showing the studied locations (modified after Srinivasalu et al., 2008). 
the prograded deltaic system of the Cauvery River. These strandlines are possibly the result of regression following the mid-Holocene sea level maximum. The ridges are dissected by the small rivers/channels and estuaries with two large rivers, (i.e.) the Palar and the Cauvery River systems.

\section{Methodology}

Post tsunami field studies have been carried out every six months since January 2005 along the northern Tamil Nadu coast and include topographic surveys using total station, identifying and measuring tsunami deposit thicknesses by digging pits and coring using PVC pipes. Several pits of approximately $40 \times 40 \mathrm{~cm}$ were excavated through the tsunami deposit and into the underlying soil. The tsunami deposits were sampled vertically for textural analyses at $1-\mathrm{cm}$ intervals. The sediment samples were analyzed for grain size distribution using a Rotap sieve shaker. Grain size parameters include the percentage of sand, silt and clay along with various statistical parameters such as mean grain size (phi), sorting (phi), skewness and kurtosis (after Folk and Ward, 1957). The foraminiferal analysis was carried out in a core sample south of Chennai (Karikattukuppam). The foraminifers were separated using simple soaking and sieving procedure. The satisfactorily clean and dried samples were examined under a microscope.

\section{Results and Discussion}

\subsection{Field characteristics of tsunami deposits}

The 2004-tsunami deposits were studied at and around Chennai, Porto Nova and Nagapattinam along the Tamil Nadu coast. The deposits were mapped using satellite imagery. Additionally, eyewitness accounts were considered in mapping the tsunami deposits. The post-tsunami survey work after the December 2004 event involved digging numerous pits and coring a number of transects using push core and extraction method. The general observations of the tsunami deposits include variable thickness, presence of marine shells (Figure 2A) and salt encrustation on the surface layers. The sediments from the near shore continental shelf and beaches are deposited in mudflats, agricultural fields (Figure 2B), backwaters and river mouths. In most of the places from Chennai to Nagapattinam, the coastal sediments were eroded and re-deposited far inland. The erosion of the beach and berm generally extends 50 to $150 \mathrm{~m}$ inland from the mean water line. However, the sedimentary characteristics of the deposits vary from north to south in the study area.

The tsunami deposits from selected locations are described below to bring out some of their characteristics. In the northern part of the Tamil Nadu coast near Injambakkam (30 $\mathrm{km}$ south of Chennai), the grain size characteristics suggests poor sorting and the deposits become finer towards the land. The deposits are characterised by an erosional base often with buried soil. The deposits near Kadalore near Palar River mouth (60 km south of Chennai) have a highly variable grain size distribution with marked coarsening in a landward direction associated with buried vegetation and soil. The coarser grain size is probably the result of differences in sampling regime, which represents coarse sand in the source sediment rather than wave energy. Due to erosion caused by tsunami inflow, the river mouths, which were closed due to accretion, were opened up after the tsunami event. The sites of river mouth opening are in the Adyar, Cooum and Palar estuaries (Figure 1). The sand, eroded from the shore and near shore areas, accumulated as tsunami sand deposits on the coastal margins. The thickness of the tsunami deposits in this region varied in thickness from a few $\mathrm{cm}$ at Chennai Marina beach to $150 \mathrm{~cm}$ in the Cooum River mouth.

A field survey was carried out in Mudasal Odai near Porto Nova in the central part of the study area during January 2005 and tsunami deposits of about $100 \mathrm{~cm}$ in thickness overlying muddy soil were found. The tsunami deposits contain a thin layer of laterally continuous laminated sand that is clearly defined by heavy mineral layers. The grain size characteristics show a single stratigraphic unit with a gradual 'fining' upward sequence. A second field survey was done in the same area after 10 months, (i.e.) during November 2005, and three different units were identified above the soil in the same location (Figure 2C). The upper part exhibits cross laminations and wavy patterns, the middle part displays cross laminations and the lower part indicates laterally continuous laminated sand. The heavy rains and floods during the subsequent monsoon season reworked the tsunami sediments and hence the deposits reveal a different internal stratigraphy. The preservation of these deposits and their associated structures requires further study as this issue may become significant when older deposits of unknown origin are considered.

The tsunami sediment characteristics in the southern part of the study area (Velankanni and Vedharanyam, Figure 1) differ from those observed in the northern and central part of the coast. The sediments in this region are very fine in nature and contain appreciable quantities of clay deposits (Figure 2D) to a maximum inundation of up to $2 \mathrm{~km}$ inland. The tsunami deposits of these regions taper inland and exhibit a wide range of thickness from less than $1 \mathrm{~cm}$ to $90 \mathrm{~cm}$. Thick deposits are accumulated in depressions such as ponds, agricultural fields (Figure 2E), backwaters and near the end of the narrow tidal creeks. The absence of coarse sand signifies the source and nature of the sediments. The deposits are graded and contain multiple 'fining' upward sequences. This study set out to look for sedimentologicalevidenceforlarge-scaleoverwashsand sheets.

The tsunami deposits at Velankanni consist of many units and contain rip-up clasts (Figure 2F). The basal unit contains thin layers of laterally continuous laminated sand that is clearly defined by heavy mineral layers (Figure 3A). The grain size characteristics of the basal unit indicate considerable variations in the lowest parts. The basal unit is sharply overlain by a massive bed of fine- to medium-grained sand with very few sedimentary features. In addition, a series of small incised channels with complex bedding structures and occasional low angle cross beds unconformably overlie this unit. This complex channel unit is overlain by a thin prominent bed that 

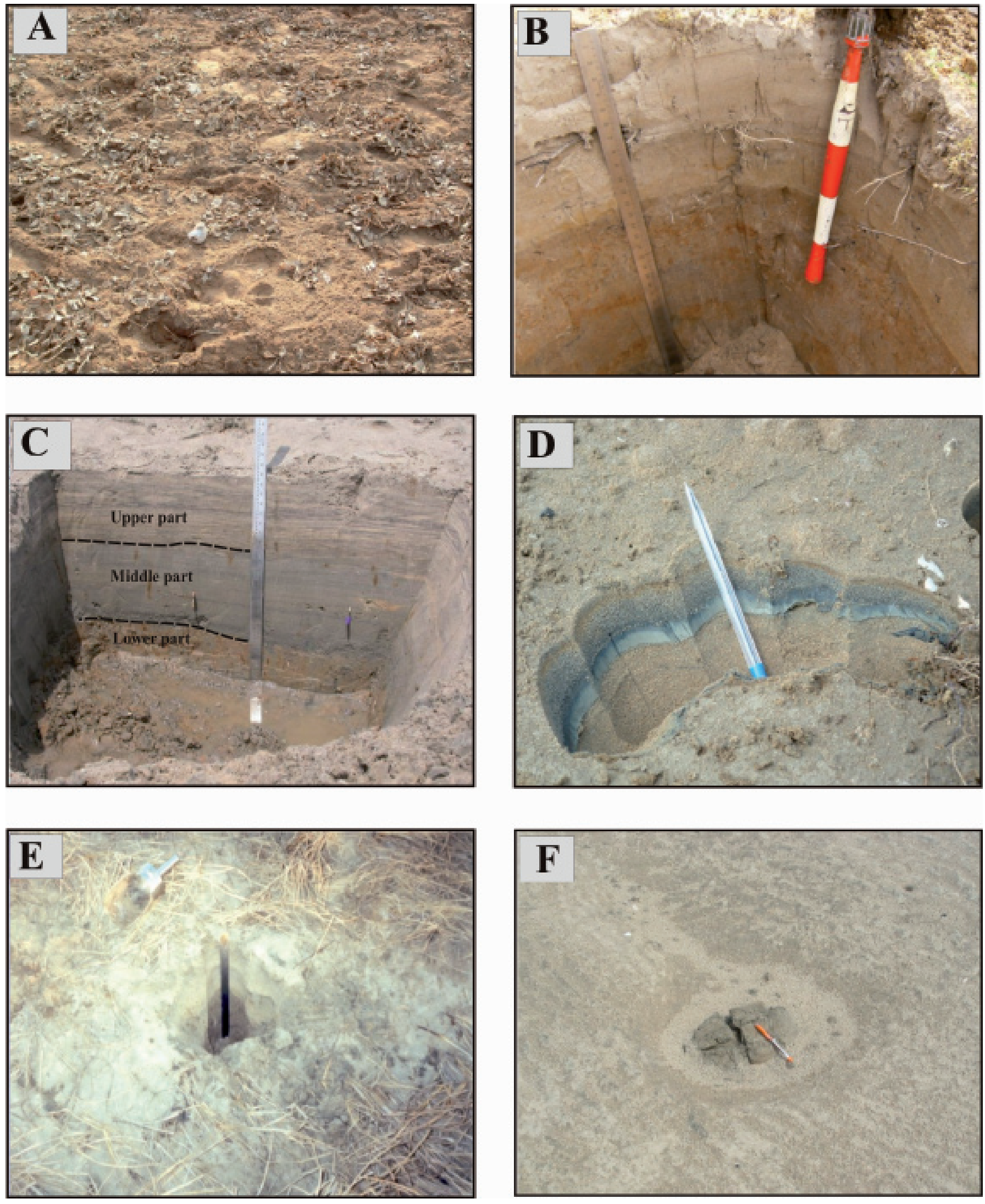

Figure 2. Tsunami deposits are characterized by (A) marine shells in Pusphavanam, (B) deposits in agricultural field near Pudhupalli, (C) reworked sediments over the original soil in Mudasal Odai, (D) clay deposits in Vedharanyam, (E) deposits in paddy field near Vilunthamavadi and (F) rip-up clasts in Velankanni. 

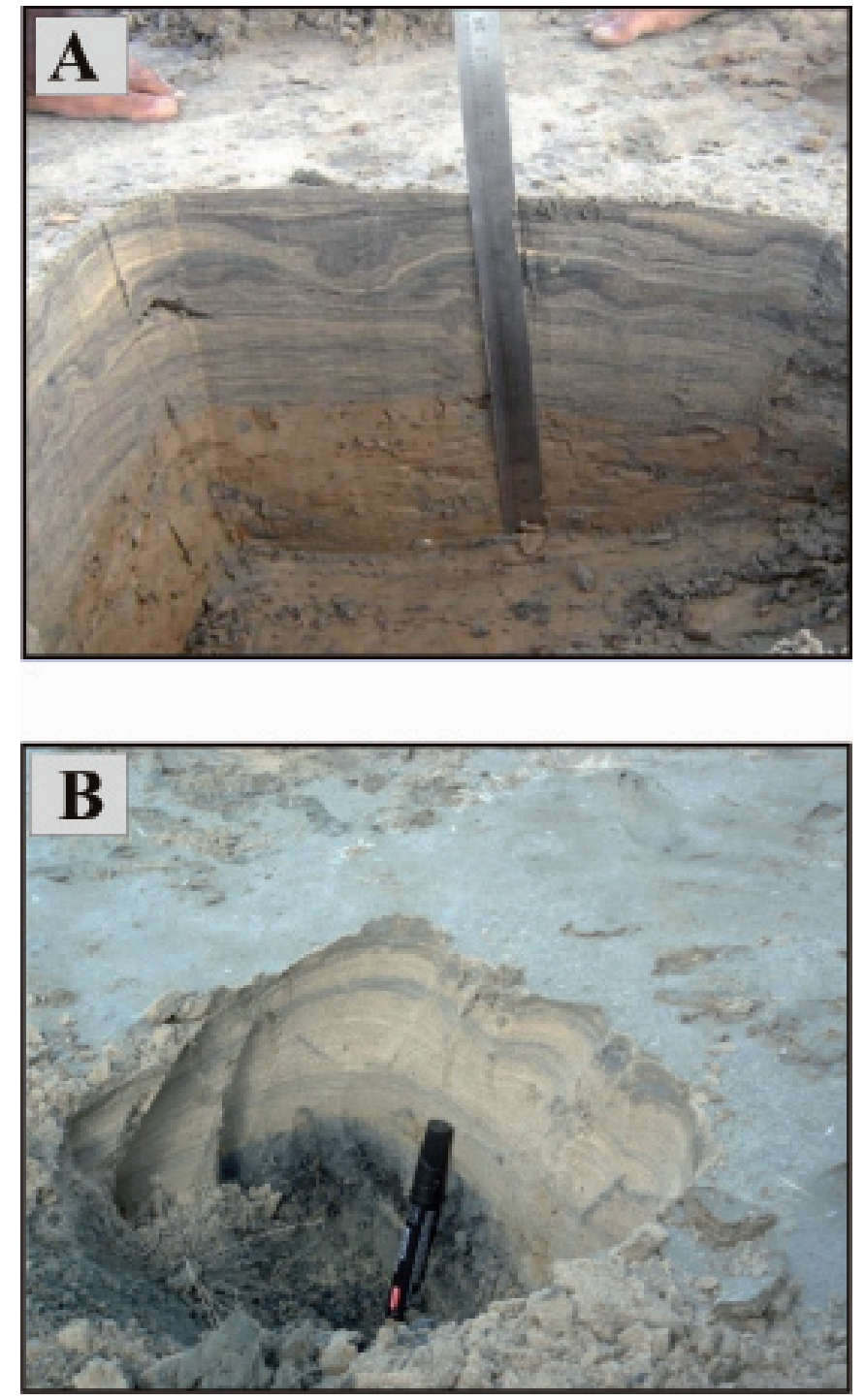

Figure 3. Tsunami deposits are characterized by (A) a series of small incised channels that unconformably overlie the tsunami deposits and contain complex bedding with occasional low angle cross bedding in Velankanni and (B) sediment deposits over black organic mud in Vedharanyam.

has a higher proportion of heavy minerals. These units exhibit poor lamination and grade into massive fine- to mediumgrained sand. The channels indicate the return flow facies of the tsunami deposits. In Vedharanyam, the sediment layers consist of well-sorted, fine sand intercalated with non-marine black organic mud (Figure 3B) that includes plant roots. The absence of sediment grading within sand layers suggests rapid sediment deposition with landward tapering and grain size fining indicates that arkosic grains were transported inland from the coast.

\subsection{Microfossils and tsunami deposits}

One of the most important criteria in identifying tsunami sediments is the association with deep sea forams. In a previous study, Hemphill-Haley (1996) considered the marine diatoms and foraminifera bearing sand layers in a lacustrine sequence as evidence for tsunami inundation in fresh water lakes and ponds. In the recent studies, Nagendra et al. (2005), Rajeshwara Rao and Charles (2005) and Hussain et al. (2006) and Bahlburg and Weiss (2007) have reported extnsively on the presence of micro-fauna in the tsunami deposits of the Tamil Nadu coast. The foraminiferal assemblages recorded in the tsunami sediments from north of Chennai and north of Pondicherry indicate an entrainment of sediment by the tsunami from the inner shelf region with a water depth of less than $30 \mathrm{~m}$ (Rajeshwara Rao and Charles, 2005; Bahlburg and Weiss, 2007). On the Nagappattinam coast, forams are inferred to have been derived from the shallow neritic zone (Nagendra et al., 2005). Hussain et al. (2006) reported that the tsunami sediments deposited on the beaches, creeks/estuaries and mangrove swamps in the Andaman Islands have been mainly derived from the shallow littoral to neritic bathymetry and not from deeper bathyal territories.

In the present study, the foraminiferal analysis was carried out in a core sample from Karikattukuppam (south of Chennai, see Figure 1) to identify the provenance of the tsunami sediment deposits. From the sub-samples analysed, 38 benthic and 1 planktic foraminiferal species were identified, many of them at the species level (Table 1). Most of the species were either partly broken or reworked. There were 39 taxa of which 24 are rotaliids, 14 are miliolids and one globigerinid, belonging to the sub-orders ROTALIINA, MILIOLINA and GLOBIGERININA, respectively. However, only the globigerinid specimen of Globigerina bulloides was recovered which was also completely pyritised. Overall, at least $50 \%$ of the foraminiferal specimens obtained in each sub-sample were fresh specimens. The number of living specimens could not be ascertained as a staining technique was not used in this study. It has been observed that a majority of the fresh specimens belong to the following species: Ammonia beccarii, A. dentata, Elphidium advenum, E. crispum, E. norvangi, Eponides cribrorepandus, E. repandus and Pararotalia nipponica. Some species such as Eponides berthelotianus, Elphidium botaniensis, Glabratellina turriformis, Glandulina laevigata, Miliolinella circularis, Nonionoides elongatum and Oolina laevigata are also represented by fresh specimens but only one each. The reworked specimens of foraminiferal species can be easily distinguished by their characteristic dirty brown colour and poor ornamentation; some of them may even be pyritised. In general, in all sub-samples reworked specimens constitute nearly $50 \%$ of the total number of specimens. These specimens belong to species such as Ammonia beccarii, A. dentata, Amphistegina radiata, Elphidium advenum, E. craticulatum, E. crispum, E. discoidale, E. norvangi, Parrellina hispidula, Quinqueloculina kerimbatica, Q. lamarckiana, Q. seminulum, Spiroloculina orbis, Triloculina rotunda, T. tricarinata and $T$. trigonula. Species which are represented by only one reworked specimen each includes Adelosina laevigata, Ammonia tepida, Cycloforina semiplicata, Massilina sp., Rupertianella rupertiana and Triloculina echinata.

The presence of Ammonia beccarii really does not give any clue about the provenance of the tsunami sediments in the Karikattukuppam region. It is unambiguously considered as 
Table 1. List of species identified from the tsunami deposits

\begin{tabular}{|c|c|c|c|c|c|c|c|c|}
\hline \multirow{2}{*}{ Species Name } & \multicolumn{7}{|c|}{ Depth range in $\mathrm{cm}$} & \multirow[b]{2}{*}{$70-80$} \\
\hline & $0-10$ & $10-20$ & $20-30$ & $30-40$ & $40-50$ & $50-60$ & $60-70$ & \\
\hline Adelosina laevigata & & & & & & & & $\mathrm{X}$ \\
\hline Ammonia beccarii & $\mathrm{X}$ & $\mathrm{X}$ & $\mathrm{X}$ & $\mathrm{X}$ & $\mathrm{X}$ & $\mathrm{X}$ & $\mathrm{X}$ & $\mathrm{X}$ \\
\hline A. dentate & & $\mathrm{X}$ & $\mathrm{X}$ & & & & & $\mathrm{X}$ \\
\hline A. tepida & $\mathrm{X}$ & & & & & & & \\
\hline Amphistegina radiata & $\mathrm{X}$ & $\mathrm{X}$ & $\mathrm{X}$ & $\mathrm{X}$ & $\mathrm{X}$ & $\mathrm{X}$ & $X$ & \\
\hline Operculina ammonides & & $\mathrm{X}$ & & & $\mathrm{X}$ & $\mathrm{X}$ & $X$ & $\mathrm{X}$ \\
\hline Asterorotalia inflata & & & & $\mathrm{X}$ & & & & $\mathrm{X}$ \\
\hline Cycloforina semiplicata & & & & $\mathrm{X}$ & & & & \\
\hline Elphidium advenum & & & & $\mathrm{X}$ & $\mathrm{X}$ & $\mathrm{X}$ & & $\mathrm{X}$ \\
\hline Eponides berthelotianus & & & & & $\mathrm{X}$ & & & \\
\hline Elphidium botaniensis & & & & $\mathrm{X}$ & & & & \\
\hline Elphidium craticulatum & $\mathrm{X}$ & & & & & & & $\mathrm{X}$ \\
\hline Elphidium crispum & $\mathrm{X}$ & $\mathrm{X}$ & $\mathrm{X}$ & $\mathrm{X}$ & & $\mathrm{X}$ & & $\mathrm{X}$ \\
\hline Elphidium discoidale & & & & & & $\mathrm{X}$ & & \\
\hline Elphidium norvangi & & $\mathrm{X}$ & & $\mathrm{X}$ & $\mathrm{X}$ & $\mathrm{X}$ & & $\mathrm{X}$ \\
\hline Elphidium spp. & & $\mathrm{X}$ & $\mathrm{X}$ & $\mathrm{X}$ & $\mathrm{X}$ & $\mathrm{X}$ & & \\
\hline Eponides cribrorepandus & & & & & & & & $\mathrm{X}$ \\
\hline Eponides repandus & $\mathrm{X}$ & $\mathrm{X}$ & & $\mathrm{X}$ & $\mathrm{X}$ & & & $\mathrm{X}$ \\
\hline Glabratellina turriformis & & & & $\mathrm{X}$ & & & & \\
\hline Glandulina laevigata & & & & $\mathrm{X}$ & & & & \\
\hline Globigerina bulloides & & & & & $\mathrm{X}$ & & & \\
\hline Massilina sp. & & & & & & & & $\mathrm{X}$ \\
\hline Miliolids & & & $\mathrm{X}$ & & & $\mathrm{X}$ & $\mathrm{X}$ & \\
\hline Miliolinella circularis & & & & $\mathrm{X}$ & & $\mathrm{X}$ & & $\mathrm{X}$ \\
\hline Nonionoides elongatum & & & & & & $X$ & & \\
\hline Oolina laevigata & $\mathrm{X}$ & & & & & & & \\
\hline Pararotalia nipponica & & $\mathrm{X}$ & $\mathrm{X}$ & $\mathrm{X}$ & $\mathrm{X}$ & $\mathrm{X}$ & $\mathrm{X}$ & $\mathrm{X}$ \\
\hline Parrellina hispidula & $\mathrm{X}$ & $\mathrm{X}$ & & $\mathrm{X}$ & $\mathrm{X}$ & $\mathrm{X}$ & & \\
\hline Poroeponides lateralis & & $\mathrm{X}$ & & & & & & \\
\hline Quinqueloculina sp. & & & & $\mathrm{X}$ & & & & \\
\hline Quinqueloculina kerimbatica & & & & & $\mathrm{X}$ & $\mathrm{X}$ & & $\mathrm{X}$ \\
\hline Quinqueloculina lamarckiana & $\mathrm{X}$ & $\mathrm{X}$ & & & $\mathrm{X}$ & $\mathrm{X}$ & & $\mathrm{X}$ \\
\hline Quinqueloculina seminulum & $\mathrm{X}$ & $X$ & & $\mathrm{X}$ & $\mathrm{X}$ & & & $X$ \\
\hline Rupertianella rupertiana & & & & & $\mathrm{X}$ & & & \\
\hline Sigmoidella elegantissima & & $\mathrm{X}$ & & & & & & \\
\hline Spiroloculina orbis & & & $\mathrm{X}$ & & & & & \\
\hline Spiroloculina sp. & & $\mathrm{X}$ & & & & & & \\
\hline Triloculina echinata & & & & $\mathrm{X}$ & & & & \\
\hline Triloculina rotunda & $\mathrm{X}$ & & & $\mathrm{X}$ & & & & \\
\hline Triloculina tricarinata & & & & & & & & $X$ \\
\hline Triloculina trigonula & & & & $\mathrm{X}$ & & $\mathrm{X}$ & & \\
\hline Total number of species & 11 & 15 & 8 & 20 & 15 & 16 & 5 & 19 \\
\hline
\end{tabular}

Note $\mathrm{X}=$ present

a cosmopolitan species worldwide with its living specimens recovered from hyposaline to hypersaline environments (e.g. Murray, 1991). Records from the Indian regions also point to its adaptability in a variety of habitats. Ammonia dentata (Parker and Jones) is known to occur in the shelf areas from near shore regions to relatively deeper waters in the Bay of Bengal. Ragothaman (1974) identified two different forms of this species: one with short, blunt spines and the other with long, slender spines. Similarly, Rajeshwara Rao (1998) observed short and blunt spines in A. dentata specimens collected from the nearshore stations. The samples collected from the inner shelf yielded specimens of the same species with long and slender spines at relatively greater water depths and with higher mud content in the substrate. This is mainly attributed to the adaptability of this species to turbulent and relatively calm conditions in the near shore and inner shelf regions, respectively. Ghosh (1966) discussed the significance of spines in Asterorotalia trispinosa (Thalmann) and inferred that the long slender spines helped the species to increase its buoyancy to remain suspended just above the substrate. 
The specimens recovered from the tsunami sediments of the Karikattukuppam (near Kalpakkam) have only short and blunt spines, indicating that the sediments have been derived from the nearshore region. The species Amphistegina radiata is typically an inner shelf species that flourishes on sandy substrates at depths ranging from 15 to $40 \mathrm{~m}$ (Rajeshwara Rao, 1998). The fresh specimens of this species in the sub-samples indicate that these sediments were derived from water depths of at least $15 \mathrm{~m}$. The bathymetry of the offshore region implies that the distance could be about 3 to $4 \mathrm{~km}$, suggesting that the sediments might have been derived from the inner shelf.

\section{Conclusions}

The overall results indicate that the character of tsunami sediments from the Tamil Nadu coast depend on the nature of the shelf sediments of the particular area. The maximum landward extent of tsunami deposits was observed at Nagapattinam in the southern part of the study area (see Figure 1). This is due to the flat topography and various river channels that acted as pathways for the sediment inundation to the nearby lands. The longitudinal ridge bordering the coast was breached in several places. Sheet sand deposits accumulated in places where tsunami flowed with high velocity. This short-lived catastrophic saltwater inundation due to the tsunami resulted in the deposition of a fining upward and thinning landward sand layer with clay lenses. The tsunami sand deposits on the east coast of India have at least two distinct layers, which were formed by series of tsunami waves. The tsunami deposits on the Tamil Nadu coast vary in thickness from few $\mathrm{cm}$ to 150 $\mathrm{cm}$. Thick deposits are observed in agricultural fields and river mouths, while those deposited on beaches are rather thin.

The presence of fresh specimens, such as elphidiids and Pararotalia nipponica (Asano), points to sediments derived from the nearshore region as these taxa are typically nearshoredwelling ones. The reworked specimens of foraminifera infer a different story, indicating the presence of a paleostrandline off the coast of Kalpakkam as reported from earlier sedimentological studies by Selvaraj and Ram-Mohan (2003) and Henriques (1993). The general results of foraminiferal studies show that at least $50 \%$ of the specimens are fresh and they are from $45 \mathrm{~m}$ water depth. Finally, the evidence from the microfossil analysis needs further study based on pre- and post-tsunami studies and the sediment depositional pattern is also dependent on the offshore bathymetry which needs to be assessed separately for each area.

\section{Acknowledgements}

We thank the CSIR and INCOIS for the financial support. This work was carried out as a part of funded research projects from CSIR (No. 23(001)/06/EMR-II) and INCOIS (No. INCOIS/283/2007).

\section{References}

Anbarasu, K., 1994. Geomorphological configuration of Tamil Nadu coast from Coleroon to Pulicat: Tiruchirapalli, India, Bharathidasan University, $\mathrm{Ph}$. D. thesis.
Atwater, B. F., 2007. Hunting for ancient tsunamis in the tropics in $4^{\text {th }}$ Annual Meeting: Bangkok, Asia Oceania Geosciences Society, SE21-A0008, 241.

Atwater, B. F., Moore, A. L., 1992. A tsunami about 1000 years ago in Puget Sound, Washington: Science, 258, 1614-1617.

Bahlburg, H., Weiss, R., 2007. Sedimentology of the December 26, 2004, Sumatra tsunami deposits in eastern India (Tamil Nadu) and Kenya: International Journal of Earth Sciences, 96, 1195-1209.

Benson, B. E., Grimm, K. A., Clague, J. J., 1997. Tsunami deposits beneath tidal marshes on northwestern Vancouver Island, British Columbia: Quaternary Research, 48, 192-204.

Bryant, E. A., Young, R. W., Price, D. M., 1992. Evidence of tsunami sedimentation on the southeastern coast of Australia: Journal of Geology, 100, 753-765.

Cisternas, M., Atwater, B. F., Torrejon, F., Sawai, Y., Machuca, G., Lagos, M., Eipert, A., Youlton, C., Salgado, I., Kamataki, T., Shishikura, M., Rajendran, C.P., Malik, J.K., Rizal, Y., Husni, M., 2005. Predecessors of the giant 1960 Chile earthquake: Nature, 437, 404-407.

Darienzo, M. E., Peterson, C. D., 1995. Magnitude and frequency of subduction-zone earthquakes along the northern Oregon coast in the past 3000 years: Oregon Geology, 57, 3-12.

Folk, R. L., Ward, W. C., 1957. Brazos River bar, a study in the significance of grain size parameters: Journal of Sedimentary Petrology, 27, 3-26.

Ghosh, B. K., 1966. Asterotalia trispinosa (Thalman): a spinose rotalid foraminifera from Digha beach, Southern Bengal: Contributions from the Cushman Foundation for Foraminiferal Research, 17, 104-108.

Goff, J., McFadgen, B. G., Chagué-Goff, C., 2004. Sedimentary differences between the 2002 Easter storm and the $15^{\text {th }}$-century Okoropunga tsunami, southeastern North Island, New Zealand: Marine Geology, 204, 235250.

Hemphill-Haley, E., 1996. Diatoms as an aid in identifying late-Holocene tsunami deposits: The Holocene, 6(4), 439-448.

Henriques, P. J., 1993. Distribution of foraminifera in surface sediments off Central (Vengurla- Mangalore) west coast of India and its paleoenvironmental significance: Goa, India, Goa University, Ph.D. Thesis.

Hussain, S. M., Krishnamurthy, R., Suresh Gandhi, M., Ilayaraja, K., Ganesan, P., Mohan, S. P., 2006. Micropalaeontological investigations on tsunamigenic sediments of Andaman Islands: Current Science, 91, 1655-1667.

Jaffe, B. E., Borrero, J. C., Prasetya, G. S., Peters, R., McAdoo, B., Gelfenbaum, G., Morton, R., Ruggiero, P., Higman, B., Dengler, L., Hidayat, R., Kingsley, E., Kongko, W., Lukijanto, Moore, A., Titov, V., Yulianto, E., 2006. Northwest Sumatra and offshore islands field survey after the December 2004 Indian Ocean tsunami: Earthquake Spectra: Earthquake Spectra, 22 (3), S105-135.

Jankaew, K., Atwater, B. F., Sawai, Y., Choowong, M., Charoentitirat, T., Martin, M. E., Prendergast, A., 2008. Medieval forewarning of the 2004 Indian Ocean tsunami in Thailand: Nature, 455, 1228-1231.

Monecke, K., Finger, W., Klarer, D., Kongko, W., McAdoo, B. G., Moore, A. L., Sudrajat, S. U., 2008. A 1,000-year sediment record of tsunami recurrence in northern Sumatra: Nature, 455, 1232-1234.

Moore, A., Nishimura, Y., Gelfenbaum, G., Kamataki, T., Triyono, R., 2006. Sedimentary deposits of the 26 December 2004 tsunami on the northwest, coast of Aceh, Indonesia: Earth Planets and Space, 58, 253-58.

Moore, A. L., 2000. Landward fining in onshore gravel as evidence for a late Pleistocene tsunami on Molokai, Hawaii: Geology, 28, 247-250.

Moore, J. G., Moore, G. W., 1984. Deposit from a giant wave on the island of Lanai, Hawaii: Science, 226, 1312-1315.

Murray, J. W., 1991. Ecology and paleoecology of benthic foraminifera: Harlow, Essex, United Kingdom, Longman Scientific and Technical, 397 p.

Nagendra, R., Kamala Kannan, B. V., Sajith, C., Gargi Sen, Reddy A. N., Srinivasalu, S., 2005. A record of foraminiferal assemblage in tsunami sediments along Nagappattinam Coast, Tamil Nadu: Current Science, 89, 1947-1952.

Nanayama, F., Satake, K., Furukawa, R., Shimokawa, K., Atwater, B. F., Shigeno, K., Yamaki, S., 2003. Unusually large earthquakes inferred from tsunami deposits along the Kuril trench: Nature, 424, 660-663.

Peters, R., Jaffe, B., Peterson, C., Gelfenbaum, G., Kelsey, H., 2001. An overview of tsunami deposits along the Cascadia Margin: Seattle, Washington, International Tsunami Symposium, Proceedings, 479-490. 
Pinegina, T. K., Bourgeois, J., Bazanova, L. I., Melekestsev, I. V., Braitseva, O.A., 2003. A millennial-scale record of Holocene tsunamis on the Kronotskiy Bay coast, Kamchatka, Russia: Quaternary Research, 59, 3647.

Ragothaman, V., 1974. The study of foraminifera off Porto Novo, Tamil Nadu State: Chennai, India, University of Madras, Ph.D Thesis.

Rajeshwara Rao, N., 1998. Recent foraminifera from inner shelf sediments of the Bay of Bengal off Karikatukuppam near Madras, South India: Chennai, India, University of Madras, Ph.D Thesis.

Rajeshwara Rao, N., Charles, D., 2005. Provenance of tsunami sheet deposit along North Chennai coast, India - a sedimentological and micropaleontological approach, in International Union of Geodesy and Geophysics: Crete, Nebraska, U.S.A, XXII International Tsunami Symposium, Proceedings, 191-197.

Satake, K., Atwater, B. F., 2007. Long-term perspectives on giant earthquakes and tsunamis at subduction zones: Annual Review of Earth and Planetary Sciences, 35, 349-374.

Selvaraj, K., Ram Mohan, V., 2003. Textural variation and depositional environment of innershelf sediments, off Kalpakkam, southeast coast of India: Journal of Geological Society of India, 61, 449-462.

Seralathan, P., Srinivasalu, S., Ramanathan, A. L., Rajamanikam, G. V., Nagendra, R., Singarasubramanian, S. R., Mukesh, M. V., Manoharan, K., 2006. Post-Tsunami sediment characterization of Tamil Nadu Coast, in Rajamanikam, G. V., Subramaniyam, B. R., Baba, M., Elango, R., Prithviraj, M. (eds.), 26 ${ }^{\text {th }}$ December 2004 tsunami: Causes, Effects, Remedial Measures, Pre and Post Tsunami Disaster Management - A Geoscientific Perspective: New Delhi, New Academic Publishers, 5982.

Srinivasalu, S., Nagendra. R., Rajalakshmi. P. R., Thangadurai. N., Arun Kumar, K., Achyuthan, H., 2005. Geological signatures of M9 tsunami event on the sediments of Tamil Nadu Coast, in Ramasamy, S. M., Kumanan, C. J. (eds.), Tsunami: In the Indian Context: Chennai, Allied Publishers, 171-181.

Srinivasalu, S., Thangadurai, N., Switzer, A. D., Ram Mohan, V., Ayyamperumal, T., 2007a. Erosion and sedimentation in Kalpakkam (N Tamil Nadu, India) from the $26^{\text {th }}$ December 2004 tsunami: Marine Geology, 240, 65-75.

Srinivasalu, S., Thangadurai, N., Switzer, A. D., Ram Mohan, V., $2007 \mathrm{~b}$. Sediment characteristics of the 2004 Indian Ocean tsunami deposits along northern Tamil Nadu coast, India: Implications for paleotsunami studies in $4^{\text {th }}$ Annual Meeting: Bangkok, Asia Oceania Geosciences Society, SE21-A0009, 241 (abstract).

Srinivasalu, S., Thangadurai, N., Jonathan, M. P., Armstrong-Altrin, J. S., Ayyamperumal, T., Ram-Mohan, V., 2008. Evaluation of trace-metal enrichments from the 26 December 2004 tsunami sediments along the southeast coast of India: Environmental Geology, 53, 1711-1721.

Thangadurai, N., Srinivasalu. S., Jonathan, M. P., Rajeshwara Rao, N., Santhosh Kumar, R., 2005. Pre-tsunami chemistry of sediment along the inner continental shelf off Ennore, Chennai, southeast coast of India: Indian Journal of Marine Sciences, 34, 274-278.

Thangadurai, N., Srinivasalu, S., Ram Mohan, V., Switzer, A. D., 2006. Erosion and sedimentation in Kalpakkam (N Tamil Nadu, India) from the 26 December 2004 M9 tsunami: Geophysical Research Abstracts, 8, 00262 .

Manuscript received: July 23, 2008

Corrected manuscript received: November 11, 2008

Manuscript accepted: November 20, 2008 